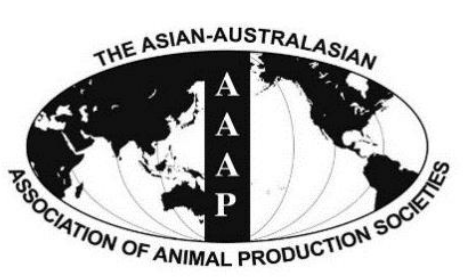

\begin{tabular}{c} 
Open Access \\
Asian Australas. J. Anim. Sci. \\
$\begin{array}{c}\text { Vol. 28, No. 8 : 1187-1193 August } 2015 \\
\text { http://dx.doi.org/10.5713/ajas.15.0056 }\end{array}$ \\
\hline www.ajas.info \\
pISSN 101 1-2367 eISSN 1976-5517
\end{tabular}

\title{
Effects of Dietary Restriction on the Expression of Lipid Metabolism and Growth Hormone Signaling Genes in the Longissimus dorsi Muscle of Korean Cattle Steers
}

\author{
H. J. Kang ${ }^{1,2}$, N. H. Trang ${ }^{1,2}$, and M. Baik ${ }^{1,2, *}$ \\ ${ }^{1}$ Department of Agricultural Biotechnology and Research Institute of Agriculture and Life Sciences, \\ College of Agriculture and Life Sciences, Seoul National University, Seoul 151-921, Korea
}

\begin{abstract}
This study determined the effects of dietary restriction on growth and the expression of lipid metabolism and growth hormone signaling genes in the longissimus dorsi muscle (LM) of Korean cattle. Thirty-one Korean cattle steers (average age 10.5 months) were allocated to normal $(\mathrm{N} ; \mathrm{n}=16)$ or dietary restriction (DR; $\mathrm{n}=15)$ groups. The feeding trial consisted of two stages: for the 8-month growing period, the DR group was fed $80 \%$ of the food intake of the normal diet, and for the 6-month growth-finishing period, the DR group was fed a DR total mixed ration with $78.4 \%$ of the crude protein and $64 \%$ of the net energy for gain of the normal diet. The LM was biopsied 5 months (period 1 [P1] at 15.5 months of age) and 14 months (period 2 [P2] at 24.5 months of age) after the start of feeding. The mRNA levels were determined using real-time polymerase chain reaction. Body weight, daily feed intake, average daily gain, and feed efficiency were lower in the DR group compared with the normal group at both P1 and P2. At P1, the lipogenic fatty acid synthase (FASN) mRNA levels were lower $(\mathrm{p}<0.05)$ in the DR group compared with the normal group. The DR group tended ( $p=0.06)$ to have higher of levels of growth hormone receptor (GHR) mRNA than the normal group. At P2, the DR group tended to have lower ( $p$ $=0.06$ ) androgen receptor $(\mathrm{AR})$ mRNA levels than the normal group. In conclusion, our results demonstrate that dietary restriction partially decreases the transcription of lipogenic FASN and growth hormone signaling $A R$ genes, but increases transcription of the GHR gene. These changes in gene transcription might affect body fat accumulation and the growth of the animals. (Key Words: Dietary Restriction, Korean Cattle Steers, Gene Expression, Longissimus Muscle)
\end{abstract}

\section{INTRODUCTION}

Gene expression is determined by both genetic and environmental factors, and the optimum environmental factors maximize the genetic potential of animals. Among various environmental factors, including nutrients and climate conditions (temperature and humidity), nutritional factors are the most important. Nutritional status affects the growth and fat accumulation of animals. For example, grain-finished cattle had twice as thick a layer of subcutaneous adipose tissue as roughage-finished cattle and

\footnotetext{
* Corresponding Author: M. Baik. Tel: +82-2-880-4809, Fax: +82-2-873-2271, E-mail: mgbaik@ snu.ac.kr

${ }^{2}$ Institute of Green Bio Science Technology, Pyeungchang 232916, Korea.

Submitted Jan. 21, 2015; Revised Feb. 25, 2015; Accepted Mar. 2, 2015
}

had a higher percentage of carcass adipose tissue (Bowling et al., 1977; Tatum et al., 1988). In a rodent study, proteinrestricted lactating rats had retarded growth and showed altered expression of lipid metabolism genes in the liver (Kwon et al., 2012). In beef cattle, dietary restriction retarded the growth of animals (Drouillard et al., 1991) and decreased body fat accumulation (Roberts et al., 2007). Diet restriction increased the concentration of growth hormone (GH) (Hayden et al., 1993).

Lipid metabolism and adipogenesis are important for body fat deposition, and GH signaling is important for animal growth. Nutritional status exerts a major influence on lipid metabolism and GH signaling, and the transcriptional regulation of the genes involved in these pathways is important. Diet restriction during the early postnatal period in mice delayed growth, altered endocrine

Copyright (? 2015 by Asian-Australasian Journal of Animal Sciences This is an open-access article distributed under the terms of the Creative Commons Attribution Non-Commercial License (http://creativecommons.org/licenses/by-nc/3.0/), which permits unrestricted non-commercial use, distribution, and reproduction in any medium, provided the original work is properly cited. 
status affecting energy/lipid metabolism, and altered expression of the genes involved in the somatotropic axis, including growth hormone-releasing hormone and growth hormone (Kappeler et al., 2009). In growing pigs, dietary energy and protein restriction retarded growth performance (da Costa et al., 2004). Da Costa et al. (2004) also reported that nutrition restriction increased the expression of genes for substrate (protein, lipid) turnover, but decreased that of the genes modulating skeletal muscle growth. However, there is limited information on the effects of nutrition on the expression of genes for lipid metabolism, adipogenesis, and growth in the muscles of cattle. Therefore, this study determined the effects of dietary restriction on the growth performance and expression of genes for lipid metabolism and GH signaling in the longissimus dorsi (LM) muscle of Korean cattle. For the gene expression study, LM tissue was biopsied twice: at 15.5 months of age, after 5 months of feeding, and at 24.5 months of age, after 14 months of feeding.

\section{MATERIALS AND METHODS}

The feeding trial was performed at the Center for Animal Science Research, Chungnam National University, South Korea. The animal use and the protocols for this experiment were reviewed and approved by the Chungnam National University Animal Research Ethics Committee.

\section{Experimental design, animals and diets}

Thirty-one Hanwoo steers $(275 \pm 5.3 \mathrm{~kg}, 10.5$ months old) were assigned randomly to 16 pens with two animals/pen. The 14-month feeding trial consisted of two stages: an 8month growing stage and a 6-month growth-finishing stage. Steers were allocated randomly to either the normal group or dietary restriction group (DR; $80 \%$ of the intake of the normal group) for 8 months during the growing stage. The major ingredients of the total mixed ration (TMR) diet during the growing stage were corn silage, Klein grass hay, flaked corn, and ryegrass hay. In the growing stage, the normal group was fed the TMR $(9.5 \%$ crude protein $[\mathrm{CP}] /$ net energy for gain $[\mathrm{NEg}])=0.63 \mathrm{Mcal} / \mathrm{kg}$ of dry matter [DM]) containing forage sources at $636 \mathrm{~g} / \mathrm{kg}$ of DM for ad libitum intake, whereas the DR steers were offered the normal diet at $80 \%$ the intake of the normal group on the previous day. One steer in the DR group was removed in the middle of the growing stage because of a mechanical accident, leaving 31 steers in the study.

Two different diets were formulated for the growthfinishing stage. In the normal diet, the major ingredients of the TMR diet consisted of alfalfa hay, timothy hay, bluegrass hay, oat straw, fine corn, and fine wheat with $12.5 \%$ $\mathrm{CP} / 1.13 \mathrm{Mcal} / \mathrm{kg} \mathrm{NEg}$, whereas the DR diet consisted of alfalfa hay, timothy hay, bluegrass hay, and oat straw with
9.8\% CP/0.72 Mcal/kg NEg. During the growth-finishing stage, the steers in both groups were fed the corresponding diets ad libitum. The experimental diets were mixed at 2week intervals. The steers were fed twice daily at 08:00 and 17:00 $\mathrm{h}$, and drinking water and mineral blocks were accessible to the animals freely. The individual feed offered and refusals were recorded daily using an automated feeding machine (TMR FEEDER; Dawoon, Incheon, Korea). Body weight was measured monthly before the morning feeding.

\section{Longissimus dorsi muscle tissue biopsy}

For the tissue biopsy, the steer was restrained in a restraining box, and the hair near the 13th rib was removed with electric hair clippers. The skin was cleaned with $70 \%$ ethanol and betadine topical solution (povidone iodine 100 $\mathrm{mg} / \mathrm{mL}$; Korea Pharm, Seoul, Korea), and anesthetized with an intramuscular (i.m.) injection of $10 \mathrm{~mL}$ of $2 \%$ lidocaine $\mathrm{HCl}$ (Dai Han Pharm, Seoul, Korea). The animals were anesthetized with an i.m. injection of $1 \mathrm{~mL}$ of Rompun (xylazine hydrochloride $23.32 \mathrm{mg} / \mathrm{mL}$; Bayer Korea, Seoul, Korea). Approximately $1 \mathrm{~cm}$ of skin was sectioned with a surgical blade to expose the LM) Approximately $5 \mathrm{~g}$ of LM tissues was taken from about $6 \mathrm{~cm}$ depth near the 13th rib using a spring-loaded biopsy instrument (Biotech Nitra, Republic of Slovakia). Immediately after the biopsy, $10 \mathrm{~mL}$ of vitamin $\mathrm{K}_{3}$ (menadione sodium bisulfite $20 \mathrm{mg} / \mathrm{mL}$; Samyang Anipharm, Seoul, Korea) was given in the surgical area i.m. to stop the bleeding. About $100 \mathrm{mg}$ of streptomycin powder (dihydrostreptomycin sulfate; Green Cross, Yongin, Korea) was applied to the surgical area to prevent infection. The biopsied area was closed with surgical sutures, and cleaned with betadine topical solution and Negasunt spray (Coumaphos 30 g, Propoxur 20 g, and Sulfanilamide $50 \mathrm{~g} / \mathrm{kg}$; Bayer Korea, Korea) and Pink spray (10 mg mercuric oxide yellow and $1 \mathrm{mg}$ prednisolone/kg; Komipharm International, Siheung, Korea). The first biopsy (five steers in the normal group, seven steers in the DR group) was taken after 5 months (period 1 [P1], average age 15.5 months), and the second biopsy (10 steers/group) 14 months after beginning feeding (period 2 [P2], average age 24.5 months). The samples were stored at $-80^{\circ} \mathrm{C}$.

\section{RNA isolation and real-time polymerase chain reaction}

Total RNA from tissues was isolated using TRIzol reagent (Molecular Research Center) according to the manufacturer's instructions. Total RNA was quantified using the absorbance at $260 \mathrm{~nm}$, and the integrity of the total RNA was checked by agarose gel electrophoresis and ethidium bromide staining of the $28 \mathrm{~S}$ and $18 \mathrm{~S}$ bands. Total RNA $(2 \mu \mathrm{g})$ was reverse-transcribed into cDNA using an iScript cDNA Synthesis kit (Bio-Rad, Hercules, CA, USA) according to the manufacturer's instructions. Real-time 
polymerase chain reaction (PCR) was performed using QuantiTect SYBR Green RT-PCR master mix (QIAGEN, Venlo, Netherlands). Briefly, the PCR was conducted in a $25-\mu \mathrm{L}$ reaction volume containing $200 \mathrm{ng}$ cDNA, $12.5 \mu \mathrm{L}$ SYBR Green RT-PCR master mix, and $1.25 \mu \mathrm{L}$ of $10 \mu \mathrm{M}$ primers. The thermal cycling parameters were as follows: $95^{\circ} \mathrm{C}$ for $15 \mathrm{~min}$, followed by 40 cycles at $94^{\circ} \mathrm{C}$ for $15 \mathrm{~s}$, $60^{\circ} \mathrm{C}$ for $30 \mathrm{~s}$ and $72^{\circ} \mathrm{C}$ for $30 \mathrm{~s}$. The primers were designed using integrated DNA technology based on published sequences at the National Center for Biotechnology Information (Table 1). The $\Delta \Delta \mathrm{CT}$ method was used to determine the relative fold changes (Livak and Schmittgen, 2001), and all data were normalized with the housekeeping beta-actin gene.

\section{Statistical analyses}

All data are presented as the mean \pm standard error of the mean. Statistical differences between the normal and DR groups were analyzed using a two-tailed $t$-test using $\mathrm{R}$ Studio for Windows ( $\mathrm{R}$ Studio, Boston, MA, USA). Pearson's correlation coefficient was obtained by correlation analysis using R Studio for Windows.

\section{RESULTS AND DISCUSSION}

\section{Growth performance}

The DR group consumed $89 \%$ and $84 \%$ of the feed intake of the normal group at P1 (11.4 vs $12.8 \mathrm{~kg} / \mathrm{head} / \mathrm{d}$ : P $=0.006)$ and P2 (11.4 vs $13.4 \mathrm{~kg} / \mathrm{head} / \mathrm{d}: \mathrm{p}<0.001)$, respectively. The DR group consumed $67 \%$ and $76 \%$ of energy intake of the normal group at P1 (1.08 vs 1.21 Mcal/head/d: $\mathrm{p}=0.006)$ and P2 (1.10 vs $1.45 \mathrm{~kg} / \mathrm{head} / \mathrm{d}$ : $\mathrm{p}<0.001)$, respectively. The DR group weighed $90 \%$ and $84 \%$ as much as the normal group at P1 (339.5 vs $375.9 \mathrm{~kg}$ :

Table 1. Primers for real time-PCR analysis

\begin{tabular}{|c|c|c|c|c|c|}
\hline Gene category & Gene name & GenBank ID & Primer & Sequence & $\begin{array}{l}\text { Length } \\
\text { (bp) }\end{array}$ \\
\hline \multirow[t]{5}{*}{$\begin{array}{l}\text { Growth hormone } \\
\text { signaling }\end{array}$} & Growth hormone receptor $(G H R)$ & NM_176608 & $\begin{array}{l}\text { Forward } \\
\text { Reverse }\end{array}$ & $\begin{array}{l}\text { cacaccagctttccttgtca } \\
\text { gaacggcacttggtgaattt }\end{array}$ & 102 \\
\hline & $\begin{array}{l}\text { Signal transducer and activator } \\
\text { of transcription 5B }(S T A T 5 B)\end{array}$ & NM_174617 & $\begin{array}{l}\text { Forward } \\
\text { Reverse }\end{array}$ & $\begin{array}{l}\text { ggctatcttgggtttcgtga } \\
\text { gatgecaccgatttcagagt }\end{array}$ & 106 \\
\hline & Insulin-like growth factor $(I G F-1)$ & NM_001077828 & $\begin{array}{l}\text { Forward } \\
\text { Reverse }\end{array}$ & $\begin{array}{l}\text { ttgcacttcagaagcaatgg } \\
\text { gtgatgggcatcttcacctt }\end{array}$ & 96 \\
\hline & Androgen receptor & NM_001244127 & $\begin{array}{l}\text { Forward } \\
\text { Reverse }\end{array}$ & $\begin{array}{l}\text { gatggggcttatggtgtttg } \\
\text { gctgtacatccgggacttgt }\end{array}$ & 124 \\
\hline & Myostatin & NM_001001525 & $\begin{array}{l}\text { Forward } \\
\text { Reverse }\end{array}$ & $\begin{array}{l}\text { gctccttggaagacgatgac } \\
\text { ttgggttttccttccacttg }\end{array}$ & 97 \\
\hline \multirow[t]{2}{*}{ Lipogenesis } & Fatty acid synthase $(F A S N)$ & NM_001012669 & $\begin{array}{l}\text { Forward } \\
\text { Reverse }\end{array}$ & $\begin{array}{l}\text { atcgagtgcatcaggcaagt } \\
\text { tgtgagcacatctcgaaagcca }\end{array}$ & 92 \\
\hline & Fatty acid binding protein $4(F A B P 4)$ & BT10868 & $\begin{array}{l}\text { Forward } \\
\text { Reverse }\end{array}$ & $\begin{array}{l}\text { gctgcacttctttctcacct } \\
\text { ttcctggtagcaaagcccac }\end{array}$ & 140 \\
\hline \multirow[t]{4}{*}{$\begin{array}{l}\text { Lipid } \\
\text { metabolism }\end{array}$} & Adipose triglyceride lipase $(A T G L)$ & NM_001046005 & $\begin{array}{l}\text { Forward } \\
\text { Reverse }\end{array}$ & $\begin{array}{l}\text { tgaccacactctccaaca } \\
\text { agtttcggaccactgtgac }\end{array}$ & 100 \\
\hline & $\begin{array}{l}\text { Acyl-CoA synthetase long-chain } \\
\text { family member }(A C S L 1)\end{array}$ & NM_001076085.1 & $\begin{array}{l}\text { Forward } \\
\text { Reverse }\end{array}$ & $\begin{array}{l}\text { tccaaccaacacgctcatgg } \\
\text { aaatacaccaggggctcgtc }\end{array}$ & 180 \\
\hline & $\begin{array}{l}\text { glycerol-3-phosphate acyltransferase } \\
\text { (GPAT1) }\end{array}$ & NM_497202 & $\begin{array}{l}\text { Forward } \\
\text { Reverse }\end{array}$ & $\begin{array}{l}\text { acgacggaggctagatgaga } \\
\text { ttccacttcttgagcgtgtg }\end{array}$ & 140 \\
\hline & $\begin{array}{l}\text { Hydroxyacyl-CoenzymeA } \\
\text { dehydrogenase }(H D A H)\end{array}$ & NM_001046334.1 & $\begin{array}{l}\text { Forward } \\
\text { Reverse }\end{array}$ & $\begin{array}{l}\text { agctgttcaagaggctggac } \\
\text { ggtggaattggctaggcttg }\end{array}$ & 95 \\
\hline \multirow[t]{2}{*}{ Fatty acid uptake } & Fatty acid translocase $(C D 36)$ & NM_174010 & $\begin{array}{l}\text { Forward } \\
\text { Reverse }\end{array}$ & $\begin{array}{l}\text { ggtccttacacatacagagttcg } \\
\text { atagcgagggttcaaagatgg }\end{array}$ & 115 \\
\hline & Lipoprotein lipase $(L P L)$ & NM_001075120 & $\begin{array}{l}\text { Forward } \\
\text { Reverse }\end{array}$ & $\begin{array}{l}\text { acttgecacctcattcctg } \\
\text { acccaactctcatacattcetg }\end{array}$ & 119 \\
\hline \multirow[t]{2}{*}{ Adipogenesis } & $\begin{array}{l}\text { Peroxisome proliferator } \\
\quad \text {-activated receptor gamma (PPARg) }\end{array}$ & NM_181024 & $\begin{array}{l}\text { Forward } \\
\text { Reverse }\end{array}$ & $\begin{array}{l}\text { agcaagtgggaaggtgtaatc } \\
\text { agctgcacgtgttctgtcac }\end{array}$ & 148 \\
\hline & $\begin{array}{l}\text { CCAAT/enhancer binding protein alpha } \\
(C / E B P \alpha)\end{array}$ & NM_176784 & $\begin{array}{l}\text { Forward } \\
\text { Reverse }\end{array}$ & $\begin{array}{l}\text { tggacaagaacagcaacgag } \\
\text { Tcattgtcactggtcagctc }\end{array}$ & 133 \\
\hline House keeping & Actin, beta $(A C T \beta)$ & NM_173979 & $\begin{array}{l}\text { Forward } \\
\text { Reverse }\end{array}$ & $\begin{array}{l}\text { agcaaagcaggagtacgatgagt } \\
\text { Atccaaccgactgctgtca }\end{array}$ & 120 \\
\hline
\end{tabular}

PCR, polymerase chain reaction. 
$\mathrm{p}=0.008)$ and $\mathrm{P} 2(458.5$ vs $547.3 \mathrm{~kg}: \mathrm{p}=0.001)$ respectively. The DR group gained $68 \%$ of the gain observed in normal group at both P1 (0.45 vs 0.66 $\mathrm{kg} / \mathrm{head} / \mathrm{d} ; \mathrm{p}<0.001)$ and P2 (0.44 vs $0.65 \mathrm{~kg} / \mathrm{head} / \mathrm{d}$; $\mathrm{p}<0.001)$. The DR group had lower feed efficiency (gain/feed $\times 100)$ compared with the normal group at P1 (3.73 vs 5.21; $\mathrm{p}=0.002)$ and P2 (4.05 vs $4.94 ; \mathrm{p}=0.04)$. Restricted feed intake is often detrimental to the performance of cattle. When both feed intake and energy intake were restricted, the average daily gain (ADG), carcass quality, and external carcass fatness decreased (Rossi et al., 2001). However, restricting dry matter intake without reducing protein or energy intake improved feed efficiency and ADG (Schmidt et al., 2005). The ADG was reduced in growing steers by $80 \%$ and $90 \%$ of the ad libitum intake, but feed efficiency was not affected by the intake levels (Murphy and Loerch, 1994). In that study, the amount of protein intake was similar for three groups through adjustments in the dietary protein concentrations. Therefore, the decreased ADG and feed efficiency at both P1 and P2 in our study may reflect a lack of both protein and energy intake in the DR group relative to the normal group.

\section{Lipid metabolism gene expression}

At P1, the DR group had lower $(p=0.04)$ lipogenic fatty acid synthase (FASN) mRNA levels in the LM than the normal group had (Figure 1A). However, this change in the DR group was not observed at P2 (Figure 2A). The FASN is a key enzyme that catalyzes the reactions in the last step of the fatty acid biosynthetic pathway (Laliotis et al., 2010).

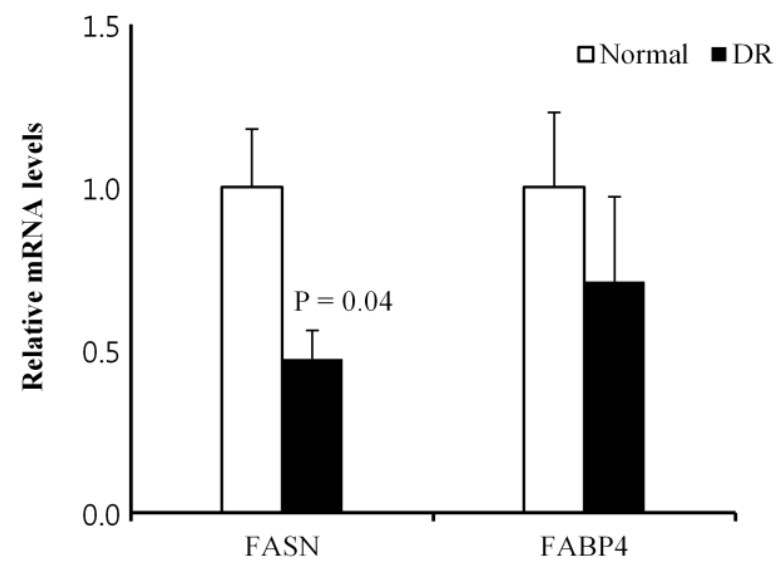

A. Lipogenic genes
Several enzymes for lipid metabolism, fatty acid uptake, and adipogenic factors are involved in body fat deposition in cattle. In this study, DR did not affect the expression of several genes in the LM for lipid metabolism (adipose triglyceride lipase, acyl-CoA synthetase long-chain family member, glycerol-3-phosphate acyltransferase, and hydroxyacyl-Coenzyme A dehydrogenase) and fatty acid uptake (fatty acid translocase and lipoprotein lipase) at both P1 and P2. Furthermore, DR did not affect the expression of several genes for lipogenesis (fatty acid-binding protein 4) and adipogenesis (peroxisome proliferator-activated receptor gamma and CCAAT/enhancer binding protein alpha) at both P1 and P2. Korean cattle steers accumulated significantly more body fat (Bong et al., 2012; Baik et al., 2014). In our previous studies, bulls and steers had differential gene expression patterns for lipid metabolism, lipogenesis, and adipogenesis in the LM (Bong et al., 2012; Jeong et al., 2013a,b; Ahn et al., 2014; Baik et al., 2014). Our study demonstrates that DR has minor effects on the expression of genes for lipid metabolism in the LM.

\section{Gene expression of growth hormone signaling}

At P1, the DR group tended $(p=0.06)$ to have higher growth hormone receptor (GHR) mRNA levels in the LM than the normal group (Figure 1B). However, this change in the DR group was not observed at P2 (Figure 2B). Several studies have reported that nutrient restriction increases the plasma GH concentration in steers (Blum et al., 1985; Hayden et al., 1993; Hornick et al., 1998). Growth signaling via the somatotropic axis is important for animal growth and meat production (Isaksson et al., 1985). The GH binds its receptor (GHR) on the membrane, which activates Janus

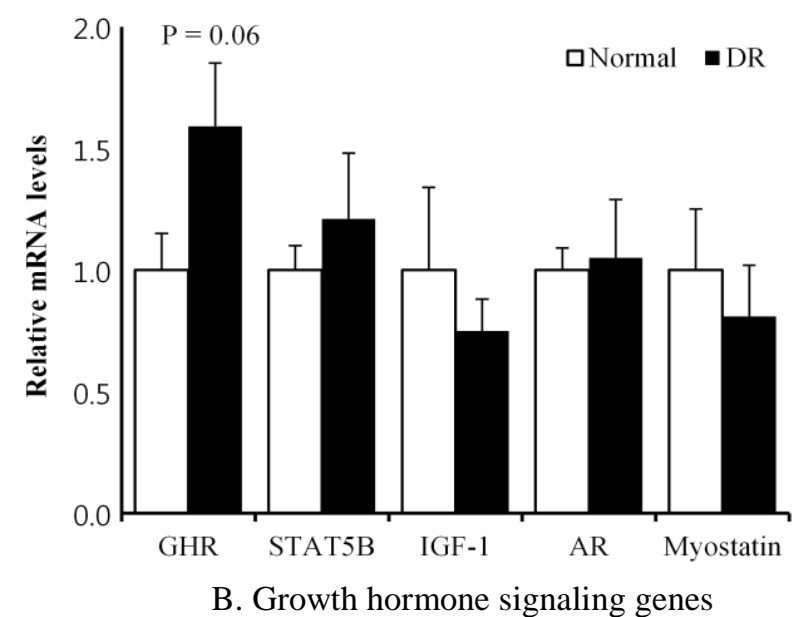

Figure 1. Comparison of the mRNA levels of lipogenesis and growth hormone signaling genes between the normal and dietary restriction (DR) groups in the biopsied longissimus dorsi muscle of Korean cattle at period 1. The mRNA levels were determined by real-time PCR, and the results were normalized with the $\beta$-actin gene. The mRNA levels of the normal group were normalized to 1.0. Values are the mean \pm SEM ( $n=5$ or 7 ). FASN, fatty acid synthase; FABP4, fatty acid binding protein 4; GHR, growth hormone receptor; STAT5B, signal transducer and activator of transcription 5B; IGF-1, insulin-like growth factor, AR, androgen receptor; PCR, polymerase chain reaction; SEM, standard error of the mean. 


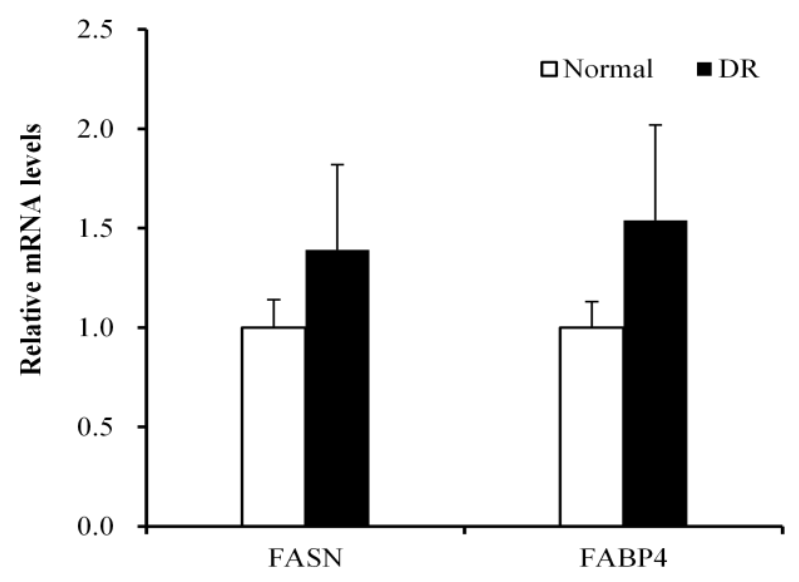

A. Lipogenic genes

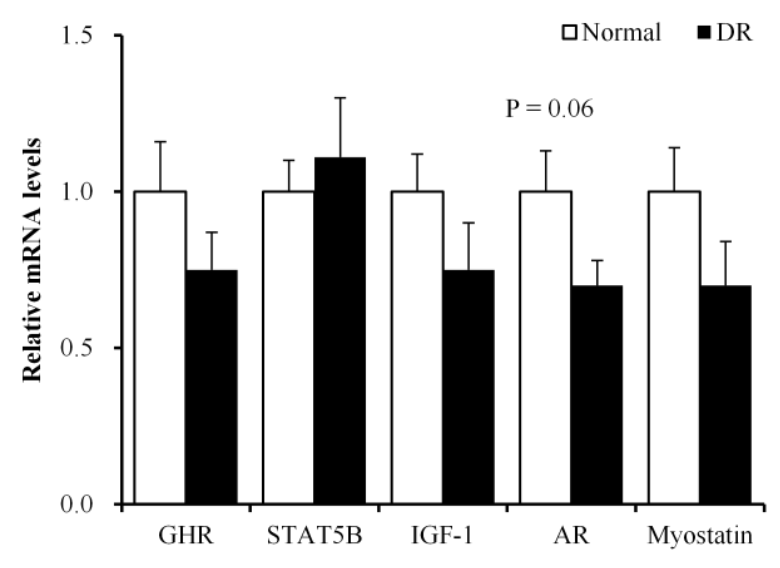

B. Growth hormone signaling genes

Figure 2. Comparison of the mRNA levels of lipogenesis and growth hormone signaling genes between the normal and dietary restriction (DR) groups in the biopsied longissimus dorsi muscle of Korean cattle at period 2. The mRNA levels were determined by real-time PCR, and the results were normalized with the $\beta$-actin gene. The mRNA levels of the normal group were normalized to 1.0. Values are the mean \pm SEM $(n=10)$. FASN, fatty acid synthase; FABP4, fatty acid binding protein 4; GHR, growth hormone receptor; STAT5B, signal transducer and activator of transcription 5B; IGF-1, insulin-like growth factor; AR, androgen receptor; PCR, polymerase chain reaction; SEM, standard error of the mean.

kinase 2, which in turn phosphorylates the signal transducer and activator of transcription 5 (STAT5) (Isaksson et al., 1985; Baik et al., 2011). Phosphorylated STAT5 translocates to the nucleus, where it binds to gamma-activated sequence motifs to regulate target genes, such as insulin-like growth factor $1(I G F-1)$. The major target organ of $\mathrm{GH}$ action is the liver (Davey et al., 2001). Klover et al. (2009) demonstrated that skeletal muscle is also an important target tissue of GH action. In beef heifers, GHR mRNA levels were greater in the muscle of low-residual feed intake (RFI) animals compared with high-RFI animals (Kelly et al., 2013). Kelly et al. (2013) suggested that GHR is important for mitochondrial metabolism in skeletal muscle by upregulating the transcription of specific genes and increasing the capacity for oxidative adenosine triphosphate generation. In pigs, the GHR mRNA levels in the muscle

Table 2. Effects of dietary restriction on gene expression for lipid metabolism in the biopsied longissimus dorsi muscle of Korean cattle steers

\begin{tabular}{|c|c|c|c|c|c|}
\hline & Period & Normal & DR & SEM & $\mathrm{p}$ \\
\hline \multicolumn{6}{|l|}{ Lipid metabolism } \\
\hline \multirow{2}{*}{ Adipose triglyceride lipase } & 1 & 1.00 & 1.20 & 0.11 & 0.41 \\
\hline & 2 & 1.00 & 0.89 & 0.14 & 0.71 \\
\hline \multirow[t]{2}{*}{ Acyl-CoA synthetase long-chain family member } & 1 & 1.00 & 0.91 & 0.10 & 0.65 \\
\hline & 2 & 1.00 & 1.14 & 0.12 & 0.59 \\
\hline \multirow[t]{2}{*}{ Glycerol-3-phosphate acyltransferase } & 1 & 1.00 & 1.14 & 0.15 & 0.65 \\
\hline & 2 & 1.00 & ND & ND & ND \\
\hline \multirow[t]{2}{*}{ Hydroxyacyl-Coenzyme A dehydrogenase } & 1 & 1.00 & 1.21 & 0.12 & 0.41 \\
\hline & 2 & 1.00 & 0.63 & 0.11 & 0.10 \\
\hline \multicolumn{6}{|l|}{ Fatty acid uptake } \\
\hline \multirow[t]{2}{*}{ Fatty acid translocase } & 1 & 1.00 & 1.47 & 0.15 & 0.14 \\
\hline & 2 & 1.00 & 1.26 & 0.13 & 0.31 \\
\hline \multirow[t]{2}{*}{ Lipoprotein lipase } & 1 & 1.00 & 1.15 & 0.16 & 0.66 \\
\hline & 2 & 1.00 & 1.23 & 0.15 & 0.47 \\
\hline \multicolumn{6}{|l|}{ Adipogenic gene } \\
\hline \multirow[t]{2}{*}{ Peroxisome proliferator-activated receptor gamma } & 1 & 1.00 & 0.86 & 0.14 & 0.65 \\
\hline & 2 & 1.00 & 1.39 & 0.18 & 0.28 \\
\hline \multirow[t]{2}{*}{ CCAAT/enhancer binding protein alpha } & 1 & 1.00 & 0.78 & 0.13 & 0.45 \\
\hline & 2 & 1.00 & 1.05 & 0.14 & 0.86 \\
\hline
\end{tabular}

DR, dietary restriction; SEM, standard error of the mean; ND, not determined. 
were higher in the low-food-intake group compared with the high-intake group (Dauncey et al., 1994). Katsumata et al. (2000) reported that the upregulation of GHR gene expression with under-nutrition was greatest in porcine LM tissues, which contain mainly fast glycolytic/oxidativeglycolytic fibers, among the four muscle tissues examined. The fast glycolytic/oxidative-glycolytic LM has a greater capacity to switch substrate utilization between glucose and lipids compared with slower oxidative muscles, such as the soleus and rhomboideus. Those authors suggested that the low-food-intake pigs were more highly dependent on fatty acids as an energy source than the high-intake animals were. Muscle might adapt to a suboptimal energy status by shifting its energy source from glucose to lipids via the upregulation of GHR gene expression. Our study also implies that the LM in the DR group is adapted metabolically to utilize more fatty acids as an energy source through the upregulation of GHR gene expression.

The maintenance of a normal muscle mass depends on androgenic hormones, such as testosterone and dihydrotestosterone. Androgen signaling is mediated through the androgen receptor (AR) (Herbst and Bhasin, 2004). Klover et al. (2009) reported that expression of the $A R$ gene in skeletal muscle is controlled by GH via STAT5 in mice. In our study, the mRNA level of the $A R$ gene in the LM at P1 was not changed with DR (Figure 1B). However, the DR group tended $(\mathrm{p}=0.06)$ to have lower AR mRNA levels at P2 than the normal group (Figure 2B). The castration of bulls retarded their growth, and higher skeletal muscle AR mRNA levels were detected in steers than in bulls (Brandstetter et al., 2000; Choi et al., 2010). The DR did not affect the expression of genes for other GH signaling, including STAT5B, IGF-1, and myostatin, at either P1 or P2. Our study demonstrates that DR partially downregulates the expression of the $A R$ gene, probably contributing to retarded muscle growth.

In current study, we had observed minor changes in gene expression: out of 7 genes tested, only one gene was changed with $\mathrm{p}<0.05$ by dietary restriction, and two genes tended $(\mathrm{p}=0.06)$ to differ by dietary restriction. Proteome

Table 3. Correlation coefficient between average daily gain, feed efficiency and FASN, FABP4, GHR, and AR mRNA levels in the LM of Korean cattle steers at period 1 and 2

\begin{tabular}{lccccc}
\hline \multirow{2}{*}{ Items } & \multicolumn{2}{c}{ Period $1(\mathrm{n}=11)$} & & \multicolumn{2}{c}{ Period $2(\mathrm{n}=26)$} \\
\cline { 2 - 3 } \cline { 5 - 6 } & ADG & FE & & ADG & FE \\
\hline FASN & $0.66^{*}$ & 0.22 & & -0.08 & -0.04 \\
FABP4 & 0.06 & -0.23 & & -0.17 & -0.04 \\
GHR & $-0.59^{*}$ & -0.47 & & 0.37 & 0.19 \\
AR & -0.04 & 0.25 & & $0.52^{*}$ & 0.30 \\
\hline
\end{tabular}

LM, longissimus dorsi muscle; ADG, average daily gain; FE, feed efficiency; FASN, fatty acid synthase; FABP4, fatty acid binding protein 4; GHR, growth hormone receptor; AR, androgen receptor. Significant correlations are indicated as $* \mathrm{p}<0.05$. or transcriptome analyses would give broader and global information.

\section{Correlation between growth and gene expression}

The FASN mRNA levels $(r=0.66, \mathrm{p}<0.05)$ at $\mathrm{P} 1$ and the AR mRNA levels $(r=0.52, \mathrm{p}<0.05)$ at $\mathrm{P} 2$ were positively correlated with the ADG (Table 3). The GHR mRNA levels at P1 were negatively correlated $(r=-0.59$, $\mathrm{p}<0.05)$ with the ADG. Further studies should examine the $F A S N, A R$, and GHR genes as molecular markers of growth performance in cattle.

In conclusion, our study demonstrates that DR partially regulates the transcription of genes for lipogenesis (FASN) and GH signaling (GHR, AR) in the LM of cattle. Our study improves our understanding of the molecular control of animal growth/diet interaction in cattle.

\section{ACKNOWLEDGMENTS}

This study was supported by grants from the Next Generation BioGreen 21 Programs (No. PJ00819103 and No. PJ01114001), Rural Development Administration, Republic of Korea and Research Resettlement Fund for the new faculty of SNU.

\section{REFERENCES}

Ahn, J., X. Li, Y. M. Choi, S. Shin, S. A. Oh, Y. Suh, T. H. Nguyen, M. Baik, S. Hwang, and K. Lee. 2014. Differential expressions of G0/G1 switch gene 2 and comparative gene identification58 are associated with fat content in bovine muscle. Lipids 49:1-14.

Baik, M., J. H. Yu, and L. Hennighausen. 2011. Growth hormoneSTAT5 regulation of growth, hepatocellular carcinoma, and liver metabolism. Ann. NY Acad. Sci. 1229:29-37.

Baik, M., T. T. T. Vu, M. Y. Piao, and H. J. kang. 2014. Association of DNA methylation levels with tissue-specific expression of adipogenic and lipogenic genes in longissimus dorsi muscle of Korean Cattle. Asian Australas. J. Anim. Sci. 27:1493-1498.

Blum, J. W., W. Schnyder, P. L. Kunz, A. K. Blom, H. Bickel, and A. Schurch. 1985. Reduced and compensatory growth: Endocrine and metabolic changes during feed restriction and refeeding in steers. J. Nutr. 115:417-424.

Bong, J. J., J. Y. Jeong, P. Rajasekar, Y. M. Cho, E. G. Kwon, H. C. Kim, B. H. Paek, and M. Baik. 2012. Differential expression of genes associated with lipid metabolism in longissimus dorsi of Korean bulls and steers. Meat Sci. 91:284-293.

Bowling, R. A., G. C. Smith, Z. L. Carpenter, T. R. Dutson, and W. M. Oliver. 1977. Comparison of forage-finished and grainfinished beef carcasses. J. Anim. Sci. 45:209-215.

Brandstetter, A. M., M. W. Pfaffl, J. F. Hocquette, D. E. Gerrard, B. Picard, Y. Geay, and H. Sauerwein. 2000. Effects of muscle type, castration, age, and compensatory growth rate on androgen receptor mRNA expression in bovine skeletal muscle. J. Anim. Sci. 78:629-637. 
Choi, B., K. Ryu, J. Bong, J. Lee, Y. Choy, S. Son, O. Han, and M. Baik. 2010. Comparison of steroid hormone concentrations and mRNA levels of steroid receptor genes in longissimus dorsi muscle and subcutaneous fat between bulls and steers and association with carcass traits in Korean cattle. Livest. Sci. 131:218-226.

da Costa, N., C. McGillivray, Q. Bai, J. D. Wood, G. Evans, and K. C. Chang. 2004. Restriction of dietary energy and protein induces molecular changes in young porcine skeletal muscles. J. Nutr. 134:2191-2199.

Dauncey, M. J., K. A. Burton, P. White, A. P. Harrison, R. S. Gilmour, C. Duchamp, and D. Cattaneo. 1994. Nutritional regulation of growth hormone receptor gene expression. FASEB. J. 8:81-88.

Davey, H. W., T. Xie, M. J. McLachlan, R. J. Wilkins, D. J. Waxman, and D. R. Grattan. 2001. STAT5b is required for GH-induced liver IGF-I gene expression. Endocrinology 142:3836-3841.

Drouillard, J. S., C. L. Ferrell, T. J. Klopfenstein, and R. A. Britton. 1991. Compensatory growth following metabolizable protein or energy restrictions in beef steers. J. Anim. Sci. 69:811-818.

Hayden, J. M., J. E. Williams, and R. J. Collier. 1993. Plasma growth hormone, insulin-like growth factor, insulin, and thyroid hormone association with body protein and fat accretion in steers undergoing compensatory gain after dietary energy restriction. J. Anim. Sci. 71:3327-3338.

Herbst, K. L. and S. Bhasin. 2004. Testosterone action on skeletal muscle. Curr. Opin. Clin. Nutr. Metab. Care 7:271-277.

Hornick, J. L., C. Van Eenaeme, M. Diez, V. Minet, and L. Istasse. 1998. Different periods of feed restriction before compensatory growth in Belgian Blue bulls: II. Plasma metabolites and hormones. J. Anim. Sci. 76:260-271.

Isaksson, O. G. P., S. Eden, and J. O. Jansson. 1985. Mode of action of pituitary growth hormone on target cells. Annu. Rev. Physiol. 47:483-499.

Jeong, J. Y., J. S. Kim, T. H. Nguyen, H. J. Lee, and M. Baik. 2013b. Wnt/ $\beta$-catenin signaling and adipogenic genes are associated with intramuscular fat content in the longissimus dorsi muscle of Korean cattle. Anim. Genet. 44:627-635.

Jeong, J., J. Bong, G. D. Kim, S. T. Joo, H. J. Lee, and M. Baik. 2013a. Transcriptome changes favoring intramuscular fat deposition in the longissimus muscle following castration of bulls. J. Anim. Sci. 91:4692-4704.

Kappeler, L., C. De Magalhaes Filho, P. Leneuve, J. Xu, N. Brunel, C. Chatziantoniou, Y. Le Bouc, and M. Holzenberger. 2009. Early postnatal nutrition determines somatotropic function in mice. Endocrinology 150:314-323.
Katsumata, M., D. Cattaneo, P. White, K. A. Burton, and M. J. Dauncey. 2000. Growth hormone receptor gene expression in porcine skeletal and cardiac muscles is selectively regulated by postnatal undernutrition. J. Nutr. 130:2482-2488.

Kelly, A. K., S. M. Waters, M. McGee, J. A. Browne, D. A. Magee, and D. A. Kenny. 2013. Expression of key genes of the somatotropic axis in longissimus dorsi muscle of beef heifers phenotypically divergent for residual feed intake. J. Anim. Sci. 91:159-167.

Klover, P., W. Chen, B. M. Zhu, and L. Hennighausen. 2009. Skeletal muscle growth and fiber composition in mice are regulated through the transcription factors STAT5a/b: linking growth hormone to the androgen receptor. FASEB J. 23:3140-3148.

Kwon, D. H., W. Kang, Y. S. Nam, M. S. Lee, I. K. Lee, H. J. Kim, P. Rajasekar J. H. Lee, and M. Baik. 2012. Dietary protein restriction induces steatohepatitis and alters leptin/signal transducers and activators of transcription 3 signaling in lactating rats. J. Nutr. Biochem. 23:791-799.

Laliotis, G. P., I. Bizelis, and E. Rogdakis. 2010. Comparative approach of the de novo fatty acid synthesis (Lipogenesis) between ruminant and non ruminant mammalian species: From biochemical level to the main regulatory lipogenic genes. Curr. Genomics 11:168-183.

Livak, K. J. and T. D. Schmittgen. 2001. Analysis of relative gene expression data using real-time quantitative PCR and the $2^{-}$ $\triangle \Delta \mathrm{CT}$ method. Methods 25:402-408.

Murphy, T. A. and S. C. Loerch. 1994. Effects of restricted feeding of growing steers on performance, carcass characteristics, and composition. J. Anim. Sci. 72:2497-2507.

Roberts, A. J., S. I. Paisley, T. W. Geary, E. E. Grings, R. C. Waterman, and M. D. MacNeil. 2007. Effects of restricted feeding of beef heifers during the postweaning period on growth, efficiency, and ultrasound carcass characteristics. J. Anim. Sci. 85:2740-2745.

Rossi, J. E., S. C. Loerch, S. J. Moeller, and J. P. Schoonmaker. 2001. Effects of programmed growth rate and days fed on performance and carcass characteristics of feedlot steers. J. Anim. Sci. 79:1394-1401.

Schmidt, T. B., K. C. Olson, M. L. Linville, J. H. Clark, D. L. Meyer, M. M. Brandt, C. A. Stahl, G. K. Rentfrow, and E. P. Berg. 2005. Effects of dry matter intake restriction on growth performance and carcass merit of finishing steers. Prof. Anim. Sci. 21:332-38.

Tatum, J. D., B. L. Klein, F. L. Williams Jr., and R. A. Bowling. 1988. Influence of diet on growth rate and carcass composition of steers differing in frame size and muscle thickness. J. Anim. Sci. 66:1942-954. 